\title{
MEKARSARI BERTANI APPLICATION BASED ON WEBSITE FOR AGRICULTURAL DATA COLLECTION IN MEKARSARI VILLAGE
}

\author{
Mochammad Haldi WIDIANTO ${ }^{*}$, Iston Dwija UTAMA ${ }^{2}$, Rachmi Kumala WIDYASARI $^{3}$, \\ Matthew Christopher ALBERT ${ }^{4}$, and Herlangga KATEJA ${ }^{5}$ \\ 1,4,5 Informatics Department, School of Computer Science, Bina Nusantara University, Jakarta, Indonesia, \\ ${ }^{2}$ Entrepreneurship Department, Business School Undergraduate Program, Bina Nusantara University, Jakarta, Indonesia, \\ ${ }^{3}$ Interior Design Department, School of Design, Bina Nusantara University, Jakarta, Indonesia, \\ mochamad.widianto@binus.ac.id*
}

\begin{abstract}
Mekarsari Village is one of the villages located in Cimaung District, Bandung Regency. This village already has plantations and quite a lot of agricultural products, especially coffee and secondary crops. The problem is, plantation processing is not easy. Farmers need expensive processing equipment, so intermediaries carry out coffee processing. Farmers only earn 1,000 rupiahs, but in fact, they can earn 10,000 rupiahs per kilogram of green coffee. Therefore, building connections between urban residents who need agricultural raw materials or farmers' plantations directly as investors is necessary. The solution given is a website-based BERTANI application to record agricultural products, farmer data used for farming. The method of making a website with a waterfall is still following the needs. The results from the data site can be used to pursue agricultural products and needs in urban areas to make appropriate and targeted technology applications. The activities carried out are (1) the preparation stage for making tools, (2) the implementation of application socialization, (3) application evaluation. The application results have been proven to positively impact the residents of the Mekarsari village because they can add to the data collection of village harvests. It is hoped that it can become a distributor in the future Mekarsari village and urban investors.
\end{abstract}

Keywords: BERTANI, Data Collection, Waterfall, Mekarsari Village

\section{BACKGROUND}

Mekarsari Village is part of Pangalengan, Cimaung District, Bandung Regency, West Java. Pangalengan is an agricultural and cattle breeding area where there is the largest milk producer in West Java, namely KPBS. Before settlement, MekarSari Village was a protected forest area. After many residents settled and started farming, the area began to change. Initially, tens of hectares of land were used as secondary crops and vegetables, such as cabbage, rice, golden chanterelle, etc. The people of MekarSari Village live by planting every day. Since the beginning of 2000 , the local government has required farmers to grow coffee as new material and become a superior product. Thus, the coffee produced by farmers has its name, namely "Puntang Coffee." This material can be processed into things like "full washing, wine, honey, natural," and the results of coffee processing are divided according to how they are processed. The most expensive processed coffee ingredients are natural because they have to go through a difficult natural process. Puntang coffee itself has been tested by several professional baristas and got a good score of 82-85, not inferior to Colombian, Kenyan coffee, etc.

The biggest potential of Mekarsari village is its coffee farming land because the coffee produced by this community if processed properly, can develop well and improve the economic quality of the village community. It's just that farmers can only plant and harvest, and no coffee processing equipment can be used to process coffee into the best quality(Hermann A. Jürgen Pohlan, 2011; Mussatto et al., 2011).

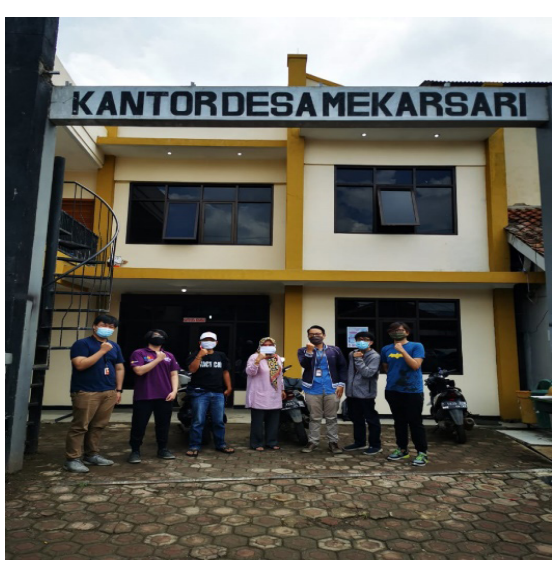

Picture 1. Mekarsari village

According to (Neilson, 2013), Coffee in Indonesia is one of the best types of coffee globally, and it can be guaranteed that the quality and quantity are very good because Indonesia has a lot of mountainous areas, especially mainland areas that have enormous economic potential. Therefore, coffee players began to study the coffee produced by the people of MekarSari Village. Usually, coffee can be harvested twice and can be done for 6 months.

After harvesting from March to August, farmers in MekarSari Village can produce 1 ton of puntang coffee purchased directly by middlemen, and the farmers themselves can earn a profit of IDR 1,000/kg. Intermediaries can process coffee, so the range is between Rp. 5000-Rp. 10000/kg (medium-high quality yield). Some middlemen do business in this village, where they can generate big business. 


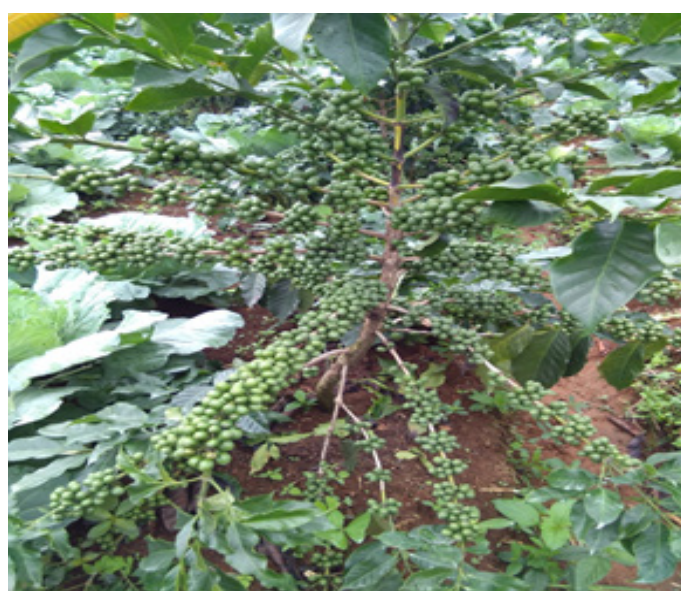

Picture 2. MekarSari Village Plants

It's not just coffee that comes from farmers, but vegetables and secondary crops they usually sell to middlemen. In 2020, the net profit of all sectors and industries of the economy had declined. It also happened in Mekarsari Village, where farmers harvest vegetables, but there is no demand to buy produce. Let farmers rot their crops. This pandemic is not a significant problem in the village. But this is another problem that plagues the entire world community. The real problem is that crops are bought cheaply by small entrepreneurs and intermediaries. After processing, the income of entrepreneurs and intermediaries can increase 9-10 times so that the circulation of money in the village is not in the hands of farmers.

Inequality between prices in urban and rural traditional markets needs to be addressed not to impact economic welfare in the village. One effort that can be made is to provide workshops or training to village officials related to online-based agricultural data collection (Bellù and Pansini, 2009; Manasa Venigalla and Chimalakonda, 2019; Widianto, 2020)after considering a set of basic questions that a quantitative policy impact analysis has usually to address in order to be useful for informing decision-making processes; some definitions and insights on policy-relevant elements such as policy objectives, policy instruments and impact models are provided. The document then briefly describes the use of counterfactual analysis for socio-economic policy impact analysis. The second part of the work focuses on the review of selected quantitative analytical approaches frequently applied to assess policy impacts, such as Value Chain Analysis (VCA to map the needs and availability of farm products in the village of Mekarsari. The holding of this online-based workshop is expected to provide knowledge and skills for Mekarsari residents in general and village officials in particular

PKM team here makes the BERTANI application to record the income of farmers, land owners, and village officials who have their crops using the waterfall method (Sun, 2005; Mukai, Sakai and Chang, 2014; Widianto, 2021). With this application, the data collection that has been carried out will be implemented in market management, investment management that solves agricultural needs, and gets fresh funds from city investors to invest their money in the Mekarsari village.

\section{METHOD}

In this community service event, the author makes an application using the waterfall method. Here are the steps for developing an application for community service to the Mekarsari village:

- Waterfall

technicians on the world's websites have used this method for a long time. This method takes a high-speed approach like a waterfall, starting from the level of system requirements and then proceeds to the stages of analysis, design, coding, testing/verification, and maintenance

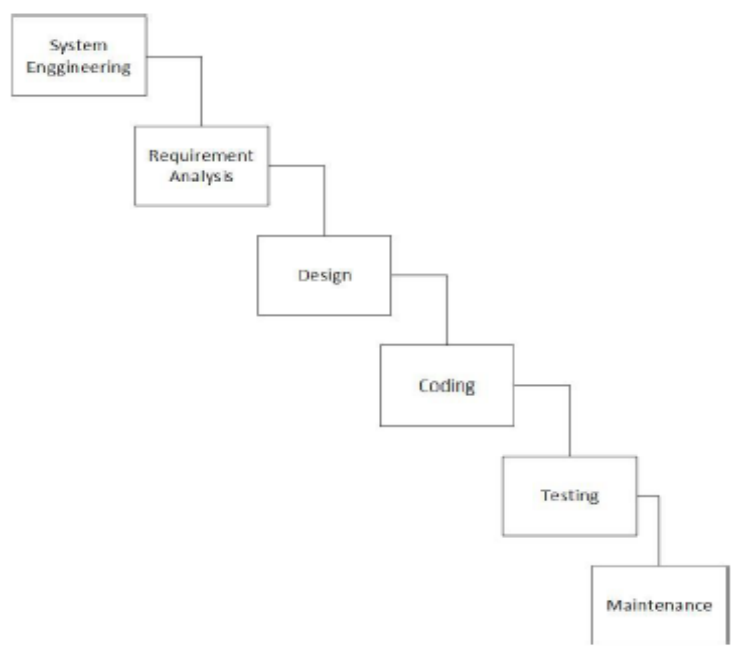

Picture 3. Waterfall Methods

Waterfall(Abadi, 2016; Gasca-Hurtado et al., 2019; Puspita, Soesanto and Muhammad, 2019; Widianto and Darisman, 2019) can be used in making BERTANI applications by following these steps:

1. System Engineering

At this stage, the author starts by looking for the village's needs regarding making the application as a whole system

2. Requirement Analysis

In this section, the author understands the BERTANI application expected by village officials and the limitations on the device's website. This kind of data is taken from the results of interviews with the Mekarsari village officials and residents

3. Design

After getting the village specifications, the author will study them at this stage and design the system

4. Coding

At this stage, the author enters the syntax section of making a website so that the information system can be used as needed.

5. Testing

All things and phases have been developed and made with really tested use, to the village by completing a questionnaire and filled in by the village apparatus 


\section{Maintenance}

the last phase after testing is done, the BERTANI website must be cared for and maintained by the author and village officials.

After knowing how to make a website-based application, the author immediately made a description of community service activities which had been divided into three stages, namely:

- Preparation Stage

For the smooth running of the website application socialization activities, it is necessary to carry out a series of preparations in the form of coordination between village officials at this moment represented by the information field of the Mekarsari village, arrangement of events, division of tasks between teams, and preparation of questionnaires for village officials present.

- Socialization Stage

At the socialization stage, the PKM team explained three main materials related to the use of the website: website introduction material, website usage material, and tutorial results that the village will use. The socialization was carried out online using software platforms and social media to facilitate coordination between village officials and the PKM team.

- Implementation and Evaluation Stage

The implementation of mentoring is carried out online and carried out by all PKM teams. Assistance is carried out until village officials know how to use the BERTANI website application. The service provided also aims to motivate village officials to resolve obstacles that occur during the development of learning models. All difficulties experienced by village officials were discussed with the PKM team.

\section{RESULT AND DISCUSSION}

Using the waterfall method, the following are the results of the PKM team's analysis of the application:

1. System Engineering

The system requirements used for the PKM team must be simple, so that village officials in the field of information and communication understand and can update the software application

2. Requirement Analysis

The real need of Mekarsari Village is the need for the data collection on agricultural products so that village agricultural products can meet farmers, landlords and the needs of the nearest town.

3. Design

The display that must be made must be simple, considering that village officials are still not familiar with the website and its use.

4. Coding

This section is only known by the PKM team, considering that the needs and designs have been determined so that the creation of a Website application using the Laravel framework is obtained. Where API needs are widely available and do not require too much effort

5. Testing

The testing stage is carried out in socialization using video conferencing devices and evaluating with an online form

6. Maintenance

The results of the socialization of the PKM team received feedback from village officials and reconfirmed by forming a social media group to find out the obstacles faced by village officials and seek solutions

The following is the result of the BERTANI application using the waterfall method, which has many uses. Here is the front view of the BERTANI website



Picture 4. BERTANI Front Display

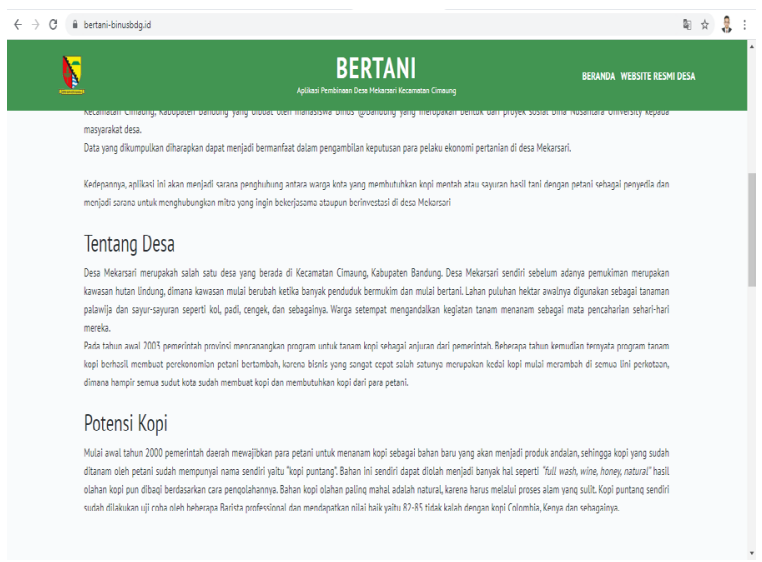

Picture 5. BERTANI Front Display

After that, the PKM team will again describe the Mekarsari Village Service activities carried out online through a software application. This activity is carried out in the form of socialization with lecture methods, discussions, and practices in using the BERTANI site and carrying out one of the contents of the Waterfall method, namely testing. This activity is aimed at the Mekarsari village apparatus, especially the information and communication section.

- Socialization Preparation Activities

Before carrying out the socialization activities, coordination was carried out between the PKM team and the Mekarsari village apparatus. This coordination aims to agree on the timing of activities and training 
materials needed by village officials. This coordination is the training required by the farmers of the Mekarsari village, who will be assisted in data collection by the village apparatus.

After that, the PKM team coordinates between members to prepare plans and materials to implement PKM. Some things that need to be designed are: technical attendance of participants, division of tasks and responsibilities of each member, etc

- Implementation of Socialization

Pelaksanaan sosialisasi dilakukan secara online dengan total peserta sekitar 18 orang hanya perangkat desa (karena kebijakan pemerintah PSBB). Kegiatan pelatihan dilakukan pada tanggal 30 Juni 2021. Kegiatan ini berdurasi sekitar 3 jam. Ada tiga materi yang dipaparkan dalam workshop ini. Materi pertama yaitu materi Penggunaan Aplikasi Website BERTANI oleh Mochammad Haldi Widianto, ST.,MT, Herlangga, Matthew dan Junwin. Materi kedua ialah pemanfaatan kantor online saat pandemi disampaikan oleh Dr. Rachmi Kumala. Kemudian materi ketiga dilanjutkan dengan pemanfaatan investasi yang berkaitan dengan hasil website BERTANI yang disampaikan oleh Iston Dwija, S.E., MBA. Kegiatan sosialisasi diakhiri dengan diskusi dan Tanya jawab yang dimoderatori oleh Mochammad Haldi Widianto, ST.,MT

The next activity was an evaluation assignment carried out by the PKM team for village officials to see the MEKARSARI website data collection results and distribute questionnaires to find out the responses of the socialization participants. The following are the results of the study conducted by the PKM team and the responses from the participants.

- Socialization Participant Response

Only part of the participants came to the socialization stage because the PSBB was imposed for the Bandung district. So the number of participants who came was 18 people consisting of 16 village officials (section heads, village secretaries, and village heads), then 2 representatives of farmers. The PKM team gave several questionnaires, including those in table 1.

Based on table 1, in the time allocation section, 10 people strongly agree, accompanied by 11 people who strongly agree that the event started well. This shows a very positive response from participants in the socialization of the BERTANI application in terms of time management. The reaction occurred because of the participants' desire to be on time accompanied by a PKM team with good time management

the usefulness of the material as many as 12 people agree that this material is beneficial for the village. As many 9 people strongly agree that the BERTANI application will be helpful for the Mekarsari village, 13 people strongly agree that the application will improve the skills of the villagers, 11 people strongly agree if this application is implemented will improve the village economy. The usefulness of the material, the participants of the socialization said they strongly agreed with the benefit of the material and application of BERTANI. This happened because before conducting the socialization, the PKM team had asked in detail what materials could be given and received by the participants.

In the material presentation section. 11 people strongly agree if the resource person has explained the material well. 9 people strongly agree if the language style is acceptable. 10 people strongly agree that if the resource person has answered the question well. 11 people strongly agree that the resource person's material can improve the selling power of rural agriculture. So that the participants have highly approved the ability of the resource persons of the socialization. This happens because the PKM team that is the resource person is very expert in the field presented

\section{Table 1. Questionnaire results from socialization participant responses}

\begin{tabular}{|c|c|c|c|c|c|c|}
\hline \multirow[b]{2}{*}{ No } & \multirow[b]{2}{*}{ Aspect } & \multicolumn{5}{|c|}{ Category } \\
\hline & & $\begin{array}{l}\text { Strongly } \\
\text { Disagree }\end{array}$ & Disagree & Enough & Agree & $\begin{array}{l}\text { Strongly } \\
\text { Agree }\end{array}$ \\
\hline \multicolumn{7}{|c|}{ Time Allocation } \\
\hline 1 & $\begin{array}{l}\text { The time allocation for the implementation of the socialization has } \\
\text { been adequate }\end{array}$ & 0 & 0 & 5 & 3 & 10 \\
\hline 2 & Timeliness of the implementation of activities & 0 & 0 & 1 & 6 & 11 \\
\hline \multicolumn{7}{|c|}{ Material Usefulness } \\
\hline 3 & The material presented is useful for participants & 0 & 0 & 1 & 12 & 5 \\
\hline 4 & The village very much needs BERTANI Application Training & 0 & 0 & 1 & 8 & 9 \\
\hline 5 & $\begin{array}{l}\text { Socialization activities can improve the skills of village officials } \\
\text { and collect data on village agricultural products }\end{array}$ & 0 & 0 & 4 & 1 & 13 \\
\hline 6 & $\begin{array}{l}\text { In the future, BERTANI Application socialization activities will } \\
\text { increase village income, especially in the agricultural sector }\end{array}$ & 0 & 0 & 3 & 4 & 11 \\
\hline \multicolumn{7}{|c|}{ Presentation of Material by Resource Person } \\
\hline 7 & Resource persons can explain the material well & 0 & 0 & 3 & 3 & 11 \\
\hline 8 & $\begin{array}{l}\text { The style of language used by the speakers is communicative and } \\
\text { easy to understand }\end{array}$ & 0 & 0 & 4 & 5 & 9 \\
\hline 9 & Resource persons can answer questions well & 0 & 0 & 4 & 4 & 10 \\
\hline 10 & $\begin{array}{l}\text { Presentation of material by resource persons can increase the } \\
\text { motivation of village officials to increase the selling power of } \\
\text { village agriculture }\end{array}$ & 0 & 0 & 6 & 1 & 11 \\
\hline
\end{tabular}


- App Results

After knowing the results of the questionnaire from the participants, the following are the results that the PKM team can give after the village apparatus has entered the needs needed in BERTANI



Picture 6. Mekarsari Village Yield Chart

In Figure 6, it can be seen that BERTANI will show yields in 1 year, such as soybeans, ginger, ginger, and coffee. So that village officials can map harvest growth which is very significant and has decreased. Village officials can provide these results to investors in urban areas

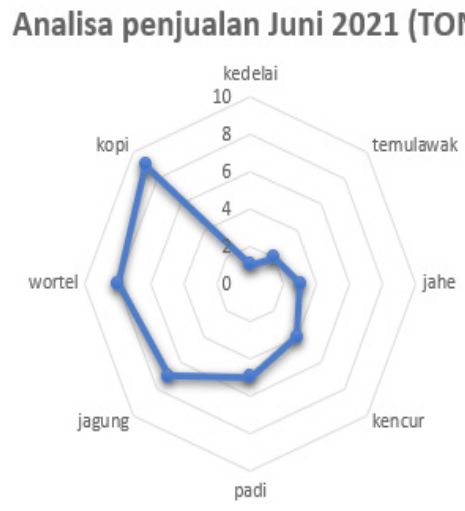

Picture 7. Mekarsari Village Sales Result Chart

In Figure 7, it can be seen that the most sales were from the village of Mekarsari. In addition to village officials knowing the most sales, city investors and other investors can see the most in-demand products by buyers themselves. This can help investors to choose which plantations to invest in
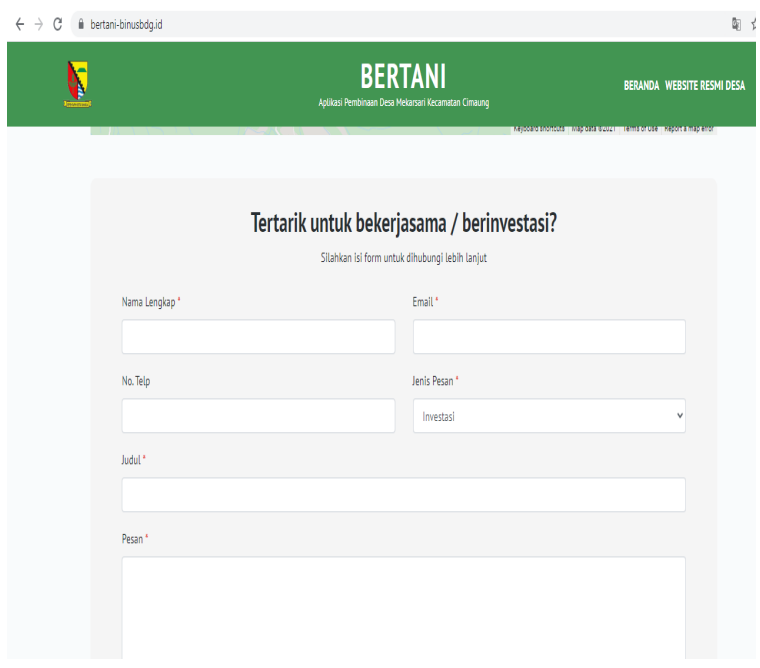

In Figure 8, if investors are already interested in some production and plantations in the village. Investors can directly fill out the form to show their interest in the town. This will be seen by the village admin and will be submitted to the relevant parties

\section{CONCLUSION}

Mekarsari village is a potential for residents of West Java because of its geographical position in the highlands. Most villagers do not know how to sell agricultural products. Usually, they sell directly to intermediaries. With the BERTANI application, you can record agricultural products and village sales. Before using this application, the PKM team made socialization used for application introduction and material exposure. The questionnaire results showed positive things because participants filled out the questionnaire with an average of strongly agreeing with the presentation of the PKM team. The application results can display crop yields and sales data that can be taken into consideration from crop yields and sales data. Investors can state their relationship in the form of BERTANI

\section{REFERENCES}

Abadi, R. G. (2016) 'Rancang Bangun Aplikasi Game Fun With Physic Berbasis Android', Jurnal Fakultas Sains dan Teknologi UIN Alauddin Makasar, p. 100. Available at: http://repositori.uin-alauddin. ac.id/638/1/rizky gita abadi.pdf.

Bellù, L. G. and Pansini, R. V. (2009) 'Quantitative Socio- Economic Policy Impact Analysis: A Methodological Introduction', pp. 1-65.

Gasca-Hurtado, G. P. et al. (2019) 'Proposal of an assessment framework for gamified environments: A case study', IET Software, 13(2), pp. 122-128. doi: 10.1049/iet-sen.2018.5084.

Hermann A. Jürgen Pohlan, V. D. P. (2011) 'SOILS, PLANT GROWTH AND CROP PRODUCTION - Vo.III - Growth and Production of Cacao', Growth \& Production of Coffee, 3 .

Komalasari, N., Budiman, J. and Fernando, E. (no date) 'Effect of Education, Performance, Position and Information Technology Competency of Information Systems to Performance of Information System', 2018 International Seminar on Research of Information Technology and Intelligent Systems (ISRITI). IEEE, pp. 221-226.

Manasa Venigalla, A. S. and Chimalakonda, S. (2019) 'Towards enhancing user experience through a webbased augmented reality museum', Proceedings IEEE 19th International Conference on Advanced Learning Technologies, ICALT 2019, pp. 357-358. doi: 10.1109/ICALT.2019.00110. 
Mukai, N., Sakai, Y. and Chang, Y. (2014) 'Waterfall simulation by using a particle and grid-based hybrid approach', Proceedings - 2014 International Conference on Cyberworlds, CW 2014, pp. 23-30. doi: 10.1109/CW.2014.12.

Mussatto, S. I. et al. (2011) 'Production, Composition, and Application of Coffee and Its Industrial Residues', Food and Bioprocess Technology, 4(5), pp. 661672. doi: 10.1007/s11947-011-0565-Z.

Neilson, J. (2013) 'The Value Chain for Indonesian Coffee in A Green Economy', Jurnal Tanaman Industri dan Penyegar, 4(3), pp. 183-198. doi: 10.21082/jtidp. v4n3.2013.p183-198.

Puspita, I. A., Soesanto, R. P. and Muhammad, F. (2019) 'Designing Mobile Geographic Information System for Disaster Management by Utilizing Wisdom of the Crowd', 2019 IEEE 6th International Conference on Industrial Engineering and Applications, ICIEA 2019. IEEE, pp. 496-500. doi: 10.1109/IEA.2019.8715031.
Sun, Z. (2005) 'A waterfall model for knowledge management and experience management', Proceedings - HIS'04: 4th International Conference on Hybrid Intelligent Systems, pp. 472-475. doi: 10.21474/ijar01/9288.

Widianto, M. H. (2020) 'Analysis of application of online work exchange using technology acceptance model and innovation diffusion theory', Journal of Theoretical and Applied Information Technology, 98(10), pp. 1697-1711.

Widianto, M. H. (2021) 'Analysis of Pharmaceutical Company Websites using Innovation Diffusion Theory and Technology Acceptance Model', Advances in Science, Technology and Engineering Systems Journal, 6(1), pp. 464 471. doi: 10.25046/ aj060150.

Widianto, M. H. and Darisman, A. (2019) 'Water Monitoring and Automatic Feed in Aquarium Based on Microcontroller', International Journal of Engineering and Advanced Technology, 9(2), pp. 1738-1743. doi: 10.35940/ijeat.b2506.129219. 